\title{
Dexamethasone therapy for bacterial meningitis: Better never than late?
}

\author{
Susan M King mD cm, Barbara Law mD, JoAnne M Langley mD, Helen Heurter rn, Diane Bremner ma, \\ ELAINE E WANG MD CM, RONALD GOLD MD
}

\begin{abstract}
SM King, B Law, JM Langley, H Heurter, D Bremner, EE Wang, R Gold. Dexamethasone therapy for bacterial meningitis: Better never than late? Can $J$ Infect Dis 1994;5(5):210-215. A multicentre randomized controlled trial was conducted in children with bacterial meningitis using dexamethasone or placebo for four days within $24 \mathrm{~h}$ of starting antibiotics. Primary outcomes were hearing loss and neurological abnormalities at 12 months after meningitis. The dexamethasone $(n=50)$ and placebo $(n=51)$ groups were similar in age, severity of illness and etiological agent. Hearing loss occurred in $10 \%$ and $11 \%$ of the dexamethasone and placebo groups and neurological deficits occurred in $20 \%$ and $18 \%$ of patients, respectively. Duodenal perforation occurred in one dexamethasone-treated child. In conclusion, there was no significant benefit in those receiving dexamethasone. The lack of benefit may have been due to the delay in administration of dexamethasone (median delay of $11 \mathrm{~h}$ after antibiotics). Therefore, if dexamethasone is used for meningitis it should be given immediately with the antibiotic.
\end{abstract}

Key Words: Bacterial meningitis, Dexamethasone, Pediatrics

\section{Traitement par dexaméthasone dans la méningite bactérienne : mieux vaut jamais que tard}

RÉSUMÉ : Un essai contrôlé, randomisé, multicentrique a été effectué auprès d'enfants atteints de méningite bactérienne et traités à l'aide de dexaméthasone ou de placebo durant quatre jours dans les 24 heures de l'amorce de l'antibiothérapie. Les principaux signes ont été la perte d'audition et certaines anomalies neurologiques douze mois après la méningite. Les groupes sous dexaméthasone $(n=50)$ et placebo $(\mathrm{n}=51)$ étaient d'un àge similaire, présentaient une maladie d'une gravité équivalente due au même agent étiologique. Une perte d'audition est a été enregistrée chez 10 et $11 \%$ des sujets du groupe dexaméthasone et placebo et les déficits neurologiques sont survenus chez 20 et $18 \%$ des patients respectivement. Une perforation duodénale est survenue chez un enfant traité par dexaméthasone. Nous en avons conclu qu'il n'y a pas d'avantages significatifs à tirer de l'administration de dexaméthasone. L'absence d'effets favorables peut avoir été attribuable au retard d'administration de la dexaméthasone (retard moyen de 11 heures après les antibiotiques). Par conséquent, si la dexaméthasone est utilisée dans la méningite, elle devrait être administrée immédiatement avec l'antibiotique.

$\mathrm{B}$ ACTERIAL MENINGITIS REMAINS A RELATIVELY COMMON and serious disease $(1,2)$. In Canada and the United States, the incidence is about three cases per 100,000 per year with a case fatality rate of 5 to $25 \%$ depending on etiology and age. Although the prognosis following bacterial meningitis improved dramatically after the intro- duction of antibiotics, there has been no major decline in the morbidity and mortality in three decades (3). Still, despite bacteriological cure there may be significant morbidity. The incidence of long term sequelae in children who survive bacterial meningitis is 25 to $50 \%$, and hearing loss alone occurs in 10\% (range 5 to $30 \%$ ) (4-6).

Presented as an abstract at the 32nd Interscience Conference on Antimicrobial Agents and Chemotherapy. American Society for Microbiology. Anaheim, California, October 12, 1992

Division of Infectious Disease, Departments of Pediatrics and Audiology. Hospital for Sick Children and University of Toronto, Toronto. Ontario; Division of Infectious Diseases, The Health Sciences Centre. Winnipeg. Manitoba; and Division of Infectious Diseases, The Izaak Walton Killam Hospital, Halifax, Nova Scotia

Correspondence and reprints: Dr Susan M King, Division of Infectious Disease, Hospital for Sick Children, 555 University

Avenue, Toronto, Ontario M5G 1X8. Telephone (416) 813-6273. Fax (416) 813-5032

Received for publication March 8, 1994. Accepted May 25, 1994 
Studies on the pathophysiology of bacterial meningitis have shown that the bacteria in the cerebrospinal fluid induce an inflammatory response in the subarachnoid space, and this inflammatory process contributes substantially to the adverse outcome of meningitis (7-12). Corticosteroids were the first antiinflammatory agents to be studied, first in animal models and then in clinical trials as adjunctive therapy for meningitis. In the animal models corticosteroids did decrease the markers of inflammatory response in the cerebrospinal fluid (13-15). In children dexamethasone appears to reduce the sequelae of meningitis (16-19). In animal models, the effect is diminished if dexamethasone is given after antibiotics (20-22). Since many children receive a dose of antibiotic before the diagnosis of meningitis is confirmed or before they are transferred to a pediatric hospital, it is important to evaluate the efficacy of dexamethasone if given after the initial dose of antibiotic. The use of dexamethasone in children with meningitis has been associated with gastrointestinal hemorrhage and, therefore, both the benefits and risks must be taken into consideration when using dexamethasone as adjunctive therapy for meningitis $(23,24)$.

The purpose of this study was to determine the effect of dexamethasone, in addition to standard antibiotic therapy, on the outcome of bacterial meningitis in infants and children when dexamethasone was given within $24 \mathrm{~h}$ of the first dose of antibiotic.

\section{PATIENTS AND METHODS}

Patients: Infants and children one month to 18 years of age who were admitted to the Hospital for Sick Children in Toronto, Ontario, the Izaak Walton Killam Hospital in Halifax, Nova Scotia and the Health Sciences Centre in Winnipeg, Manitoba with the diagnosis of suspected bacterial meningitis were eligible for enrolment in the study. The study protocol was approved by each institution's research ethics review committee and informed consent obtained from the parents or guardians of each patient before enrolment. Children were excluded from the study for any of the following: a history of antecedent hearing or neurological disorder; a previous episode of meningitis; congenital or acquired immunodeficiency syndromes; the presence of a ventricular shunt; or current use of steroids or a contraindication to the use of steroids, such as peptic ulcer disease. Patients were also excluded if they had received the first dose of intravenous antibiotic $24 \mathrm{~h}$ or more previously.

The diagnosis of suspected meningitis was made on clinical grounds by the admitting pediatrician. Patients were eligible if, as well as the clinical diagnosis, the cell count in the cerebrospinal fluid (CSF) was more than $1000 \times 10^{6}$ white blood cells/L or between 100 and $1000 \times 10^{6}$ white blood cells/L with neutropenia or sepsis. Patients were also eligible if they were assumed to have bacterial meningitis but were too unstable for a lumbar puncture. In all cases the lumbar puncture was performed when stability was attained. Confirmed cases of bacterial meningitis had more than $1000 \times 10^{6}$ white blood cells/L in the CSF and at least one of the following: bacteria seen on Gram stain, recovery of bacteria or the presence of bacterial antigens. Patients were evaluable if the etiological agent was Haemophilus influenzae type b, Neisseria meningitidis, Streptococcus pneumoniae or group B streptococcus. In addition, cases were considered confirmed if there was CSF pleocytosis (greater than $1000 \times 10^{6}$ white blood cells/L) and one of the bacteria listed above was recovered from blood. Probable cases of bacterial meningitis were those cases to whom antibiotics were given before CSF was obtained and those in whom no bacteria were identified but the CSF had greater than $1000 \times 10^{6}$ white blood cells/L, of which more than 50\% were polymorphonuclear cells.

Treatment: Patients were treated with empirical intravenous antibiotics in accordance with the guidelines of each institution. During the first two months of the study cefuroxime was used for empirical therapy and was received by six subjects. For the remainder of the study period ceftriaxone was used for empirical therapy except in infants under three months of age, for whom ampicillin and cefotaxime were used. The standard duration of antimicrobial therapy for an uncomplicated case at the participating institutions is seven to 10 days for $H$ influenzae, five to seven days for $N$ meningitidis, seven to 14 days for $S$ pneumoniae and 14 to 21 days for group B streptococcus.

Patients were randomized to receive either dexamethasone or an equal volume of placebo (normal saline) in a double-blind manner for four days. The randomization was stratified by centre and by age greater or less than five years. Dexamethasone sodium phosphate $0.6 \mathrm{mg} / \mathrm{kg} /$ day was given intravenously every $6 \mathrm{~h}$.

Additional supportive care was administered according to standard clinical practice at each institution.

Evaluation of therapy: At enrolment, patients were assessed and scored by a pediatric study nurse or investigator according to the pediatric Glasgow coma scale and the Herson-Todd meningitis severity score (25-27). Neurological status and temperature were monitored daily throughout hospitalization. Persistent fever (temperature over $38.5^{\circ} \mathrm{C}$ orally) was defined as daily fever for more than five consecutive days. Secondary fever was defined as a recurrence of fever after at least $24 \mathrm{~h}$ without fever. In addition, complete blood count, serum electrolytes, blood glucose and stool for occult blood were monitored daily for the first four hospital days.

Hearing was assessed at six weeks and one year after discharge. Hearing tests were selected according to the child's ability to cooperate. Children under 24 to 30 months of age were tested by behaviour observational audiometry or visual reinforced audiometry $(28,29)$. If clinically indicated, brainstem auditory evoked re- 
TABLE 1

Characteristics of the study patients on admission by treatment group

\begin{tabular}{lcc}
\hline & $\begin{array}{c}\text { Dexamethasone } \\
\mathrm{n}=50\end{array}$ & $\begin{array}{c}\text { Placebo } \\
\mathrm{n}=51\end{array}$ \\
$\begin{array}{l}\text { Median age in months } \\
\text { (range) }\end{array}$ & 13 & 11 \\
$\begin{array}{l}\text { Sex: number (\%) } \\
\text { Male }\end{array}$ & $(2-146)$ & \\
Female & $25(50)$ & $20(39)$ \\
Race: number (\%) & $25(50)$ & $31(61)$ \\
Caucasian & & \\
Black & $40(83)$ & $38(76)$ \\
Other & $2(4)$ & $3(6)$ \\
Median Herson-Todd & $6(13)$ & $9(18)$ \\
meningitis score (range) & $2(0-4.5)$ & $2(0-6)$ \\
Median Glasgow coma & $12.5(6-15)$ & $13(6-15)$ \\
score (range) & & $11(22)$ \\
Number with seizures & $8(16)$ & $14(28)$ \\
before admission (\%) & $14(28)$ & \\
Number given oral anti- & & \\
biotics before admission (\%) &
\end{tabular}

sponses were performed. Hearing impairment was defined as mild if the auditory threshold was 21 to $40 \mathrm{~dB}$, moderate if 41 to $70 \mathrm{~dB}$, severe if 71 to $90 \mathrm{~dB}$ and profound if greater than $90 \mathrm{~dB}$. The diagnosis of sensorineural hearing loss was based on the results of at least two hearing evaluations.

Complete physical and neurological examinations were performed by a pediatric infectious disease specialist at six weeks, six months and one year. Patients were assessed by a pediatric neurologist and a clinical psychologist at six to 12 months after discharge. Children under 30 months of age were tested using the Bayley Scales of Infant Development (Mental Development Index [MDI] and Psychomotor Development Index [PDI]), two- to four-year-olds using the Stanford-Binet and Wechsler Preschool and Primary Scale of Intelligence, four- and five-year-olds using the Wide Range Achievement Test and children over six years old using the Wechsler Intelligence Scale for Children (Third Edition).

Statistical analysis: Because the data were not always distributed in a statistically normal fashion, differences between the values for the two groups were tested for significance with the Mann-Whitney U test. Differences for frequencies were compared either by the $\chi^{2}$ or Fisher's exact test. $\mathrm{P} \leq 0.05$ was considered to be statistically significant.

\section{RESULTS}

Study patients: Between March 1989 and June 1991, 118 patients were enrolled in the study, of whom 17 were excluded - nine from the dexamethasone group and eight from the placebo group. The diagnoses of excluded cases were aseptic meningitis (seven), enteroviral meningitis (three), recurrent meningitis (one),
TABLE 2

Laboratory characteristics of the study patients by treatment group

\begin{tabular}{lcc}
\hline & $\begin{array}{c}\text { Dexamethasone } \\
\mathrm{n}=50\end{array}$ & $\begin{array}{c}\text { Placebo } \\
\mathrm{n}=51\end{array}$ \\
$\begin{array}{l}\text { Number with bacteremia (\%) } \\
\text { Etiological agent: number (\%) }\end{array}$ & $32(65)$ & $35(70)$ \\
Haemophilus influenzae & $29(58)$ & $28(55)$ \\
$\quad$ type b & & \\
Streptococcus pneumoniae & $7(14)$ & $6(12)$ \\
Neisseria meningitidis & $7(14)$ & $11(21)$ \\
Group B streptococci & $1(2)$ & $0(0)$ \\
No isolate & $6(12)$ & $6(12)$ \\
Findings in cerebrospinal fluid at diagnosis* & \\
Total white blood cells & $3070 \pm 2510$ & $2956 \pm 3221$ \\
$\quad$ (10 $/ \mathrm{L}$ ) & & \\
Protein ( $\mathrm{g} / \mathrm{L}$ ) & $2.50 \pm 1.87$ & $2.01 \pm 1.73$ \\
Glucose (mmol/L) & $1.99 \pm 1.73$ & $2.36 \pm 1.35$ \\
Positive Gram stain: & $34(71)$ & $34(67)$ \\
$\quad$ number (\%) & & \\
Positive culture: number (\%) & $40(80)$ & $39(77)$ \\
\hline Means are given $\pm S D$ & &
\end{tabular}

pineal tumour (one) and other bacterial causes of meningitis (five), including Escherichia coli (two), salmonella (one), enterobacter (one) and H influenzae nontype b (one). During the study period 12 eligible children were inadvertently missed, nine parents refused consent and, in two cases, the treating physicians refused because they wanted to treat with dexamethasone. Of the remaining 101 patients, 50 were assigned to the dexamethasone group and 51 to the placebo group.

Clinical and laboratory features: The two groups of patients were similar in age, sex and race (Table 1). The groups were also similar in the proportion who were bacteremic and in the causative agent of meningitis, with only $56 \%$ overall of the cases due to $H$ influenzae type b. Six patients in each group had no organism isolated and were classified as probable cases of bacterial meningitis. There were no statistically significant differences between the groups in their clinical characteristics or in their CSF at enrolment (Table 2). In both groups the median time from the first dose of intravenous antibiotic to administration of the study drug was $11 \mathrm{~h}$. Only eight patients in the dexamethasone group and seven in the placebo group received the study drug within $4 \mathrm{~h}$ of the first dose of antibiotic. Most children received a third-generation cephalosporin as empirical therapy - $92 \%$ in the dexamethasone group and $88 \%$ in the placebo group. The antibiotic was changed to a penicillin in 62 and $67 \%$ of the groups, respectively, when the etiological agent was identified as sensitive to penicillin or ampicillin.

Response to therapy - Long term sequelae: Ninety three per cent of the children had one or more audiological assessments (Table 3). Eighty-five per cent had a second audiological assessment at one year after men- 
TABLE 3

Sequelae in study patients by treatment group

\begin{tabular}{lcc}
\hline & Dexamethasone & Placebo \\
\hline Hearing impairment & $n=48$ & $n=45$ \\
Mild loss (\%) & $3(6.3)$ & $2(4.4)$ \\
Moderate-severe loss (\%) & $2(4.2)$ & $3(6.7)$ \\
Any hearing loss (\%) & $5(10.4)$ & $5(11.1)$ \\
Neurological status & $n=46$ & $n=44$ \\
Abnormal (\%) & $5(10.9)$ & $3(8.6)$ \\
Psychological status & $n=37$ & $n=35$ \\
Abnormal/delay (\%) & $4(10.8)$ & $3(8.6)$ \\
Any sequelae (\%) & $10(20)$ & $9(17.6)$ \\
\hline
\end{tabular}

TABLE 4

Outcome of meningitis by etiological agent

\begin{tabular}{|c|c|c|c|c|c|c|}
\hline & \multicolumn{2}{|c|}{ Number } & \multicolumn{2}{|c|}{$\begin{array}{l}\text { Any hearing } \\
\text { loss }(\%)\end{array}$} & \multicolumn{2}{|c|}{$\begin{array}{c}\text { Any deficit } \\
(\%)\end{array}$} \\
\hline & D & $P$ & D & $\mathrm{P}$ & D & $P$ \\
\hline $\begin{array}{l}\text { Haemophilus } \\
\text { influenzae }\end{array}$ & 29 & 28 & 11 & 14 & 22 & 29 \\
\hline $\begin{array}{l}\text { Streptococcus } \\
\text { pneumoniae }\end{array}$ & 7 & 6 & 29 & 17 & 43 & 17 \\
\hline $\begin{array}{l}\text { Neisseria } \\
\text { meningitidis }\end{array}$ & 7 & 11 & 0 & 0 & 0 & 0 \\
\hline $\begin{array}{l}\text { Group B } \\
\text { streptococcus }\end{array}$ & 1 & 0 & 100 & - & 100 & - \\
\hline No isolate & 6 & 6 & 0 & 0 & 0 & 0 \\
\hline All causes & 50 & 51 & 10 & 11 & 20 & 18 \\
\hline
\end{tabular}

D Dexamethasone; P Placebo

ingitis. All children with equivocal or abnormal initial assessments had at least one further assessment. Five children in each group had hearing loss with moderate to severe losses in five cases - two in the dexamethasone group and three in the placebo group. One child in each group required a hearing aid.

There were no statistically significant differences between the two groups in the incidence of one or more types of neurological sequelae. The numbers of children with any long term sequelae after meningitis were 10 $(20 \%)$ and nine $(17.6 \%)$ in the dexamethasone and placebo groups, respectively (Table 3). There was a single death during the study, in the placebo group on day 2. Ninety per cent of the children had neurological assessments at six to 12 months after meningitis. The 10 children not returning for neurological evaluation were neurologically normal at the time of discharge from hospital. Five children in the dexamethasone group had persistent neurological abnormalities: multiple handicaps of hemiparesis, visual loss, seizures and severe developmental delay (one); ataxia (one); mild hypotonia (one); and speech delay (two). Three children in the placebo group had persistent neurological abnormalities: multiple handicaps of hemiparesis, seizures and severe developmental delay (one); gross motor delay (one); and mild hypotonia (one). An additional five
TABLE 5

Outcome of hearing loss after meningitis grouped by age, empirical antibiotic and time to dexamethasone or placebo

\begin{tabular}{lcc}
\hline \multicolumn{3}{c}{ Number with any hearing loss } \\
Dexamethasone & Placebo \\
\hline $\begin{array}{c}\text { Age (years) } \\
\leq 1\end{array}$ & $1 / 22$ & $4 / 24$ \\
$1-5$ & $4 / 23$ & $1 / 13$ \\
$>5$ & $0 / 5$ & $0 / 9$ \\
Antibiotics & & \\
Cefuroxime & $0 / 2$ & $0 / 4$ \\
Ceftriaxone & $4 / 36$ & $5 / 33$ \\
Cefotaxime & $0 / 10$ & $0 / 7$ \\
Ampicillin & $1 / 2$ & $0 / 2$ \\
Time to dexamethasone or placebo (h) & \\
$\leq 12$ & $5 / 31$ & $2 / 25$ \\
$>12$ & $0 / 19$ & $3 / 21$ \\
\hline
\end{tabular}

children had neurological abnormalities at six weeks after meningitis but were normal at 12 months after meningitis. The abnormalities that resolved were mild hemiparesis (two); sixth cranial nerve palsy (one); ataxia (one); and developmental delay (one).

Seventy-two per cent of the children had psychometric assessments. In the dexamethasone group there were four children with abnormalities: developmental delay (one) and language delay (three). In the placebo group there were three children with abnormalities: developmental delay (one), gross motor delay (one) and language delay (one).

The outcome of meningitis for each etiological agent and for probable cases is shown in Table 4. Table 5 summarizes the hearing outcome by age group, antibiotic group and interval to the intervention. None of the proportions were significantly different, although, given the small numbers in each subgroup, there would be limited power to detect even major differences in incidence.

Course in hospital: As shown in Table 6, the median number of days of fever was one day in the dexamethasone group and 1.5 days in the placebo group $(\mathrm{P}>0.05)$. Fewer children in the dexamethasone group had prolonged primary fever - three $(6 \%)$ compared with eight $(16 \%)$ in the placebo group $(\mathrm{P}<0.01)$. The incidence of secondary fever was similar in both groups.

No significant differences were observed between the groups in the incidence of electrolyte abnormalities, hyperglycemia or hypertension. The percentage of children whose stools were positive for occult blood were 29 and $23 \%$, respectively. One child in the dexamethasone group developed gastrointestinal bleeding with duodenal perforation on the second hospital day. This child had no antecedent history, no family history and no findings on physical examination that would have suggested that she was at increased risk for gastrointestinal bleeding. One child in the placebo group had 
TABLE 6

Clinical events in hospital in patients by treatment group

\begin{tabular}{|c|c|c|}
\hline & $\begin{array}{l}\text { Dexamethasone } \\
n=50\end{array}$ & $\begin{array}{c}\text { Placebo } \\
n=51\end{array}$ \\
\hline Number of deaths & 0 & 1 \\
\hline Median hospital days (range) & $8(7-23)$ & $8(7-40)$ \\
\hline $\begin{array}{l}\text { Median days of fever per } \\
\text { patient (range) }\end{array}$ & $1(0-10)$ & $1.5(0-24)$ \\
\hline $\begin{array}{l}\text { Median days of primary fever } \\
\text { per patient (range) }\end{array}$ & $1(0-10)$ & $1(0-24)$ \\
\hline $\begin{array}{l}\text { Number with primary fever } \\
\text { (fever }>5 \text { days) }\end{array}$ & 3 & $8^{*}$ \\
\hline Number with secondary fever & 4 & 3 \\
\hline Stool occult blood-positive (\%) & 29 & 23 \\
\hline $\begin{array}{l}\text { Number with gastrointestinal } \\
\text { bleed }\end{array}$ & $1^{\dagger}$ & $1^{\ddagger}$ \\
\hline
\end{tabular}

disseminated intravascular coagulopathy with bleeding from many sites including the gastrointestinal tract.

The median length of stay in hospital was eight days for both groups (range seven to 40).

\section{DISCUSSION}

Early studies of the use of dexamethasone in children with bacterial meningitis suggested lack of efficacy $(30,31)$ but animal studies confirmed its anti-inflammatory effect in meningitis (13-15,20-22). Before the start of this study two trials conducted at the same centre found a beneficial effect of dexamethasone on hearing loss after meningitis (16). However, in those trials the rate of hearing loss was high compared with previous studies (32-34). Based on the animal studies dexamethasone would more likely be expected to be beneficial if given early and, preferably, before administration of antibiotic $(20,21)$. However, antibiotics are frequently administered to children before the diagnosis of meningitis has been made and, therefore, the clinician must decide whether dexamethasone would be beneficial after the administration of antibiotic. This study was conducted to determine whether dexamethasone given within $24 \mathrm{~h}$ of antibiotic administration would decrease hearing loss and neurological sequelae after meningitis. No benefit was observed in long term sequelae.

This study was stopped early on the recommendation of the steering committee because of a conflict between research and clinical practice. As approved by each of the participating centre's institutional ethics review board, children were enrolled after informed consent was obtained. Since antibiotics were always started as soon as meningitis was diagnosed, but the study drug was given after specific consent for the study was obtained, a time interval was necessary between administration of antibiotic and study drug. During the present study the results of another similar randomized controlled trial of dexamethasone in meningitis were published (19). Many clinicians were con- vinced that if steroids were to be given they should be given early, which is the recommendation of the American Academy of Pediatrics (23). Therefore, continuation of the present study would have meant delay in the administration of steroids, which would have been in conflict with the new standard clinical practice.

The role of dexamethasone in children with meningitis remains controversial $(23,24)$. In two subsequent randomized controlled trials, one supported (18) and the other refuted (19) the benefit of dexamethasone. Two factors that may have contributed to the differences in results among studies are the timing of administration of dexamethasone and varying etiological bacterial agents over time. The present study differed from others in that the antibiotic was changed from a third-generation cephalosporin to penicillin or ampicillin if a penicillin- or ampicillin-sensitive organism was identified. This management difference is unlikely to have had an impact on the effect of steroids, since any effect of steroids would likely have occurred early, before the change in antibiotic.

In this study the median time between antibiotic and dexamethasone administration was $11 \mathrm{~h}$, with only eight of the 50 cases in the dexamethasone group receiving dexamethasone within $4 \mathrm{~h}$. In the four trials reporting efficacy, dexamethasone was given immediately before antibiotics in two $(17,18)$ but the interval was not reported for the other trials (16). In the trial reporting lack of benefit, dexamethasone was administered within $4 \mathrm{~h}$ (19). When hearing was assessed within $24 \mathrm{~h}$ of admission hearing loss was found frequently to be an early event (19). This is consistent with previous literature on hearing loss in meningitis $(35,36)$. In the eight-year period over which these trials were conducted (1984 to 1992), the introduction of the $H$ influenzae type $\mathrm{b}$ (Hib) vaccine has resulted in a decreased incidence of Hib disease (37). In early trials the proportions of cases due to $H$ influenzae were 77 to $78 \%$ (16) and in recent trials 56 to $58 \%$ (17-19). Currently the proportion of cases due to $H$ influenzae is even lower and, therefore, generalizing the results of these studies to current practice must be done with caution.

Given the potentially life-threatening adverse complication of gastrointestinal bleeding in up to $2 \%$ of dexamethasone recipients in these trials without any observed evidence of benefit of therapy, there is no basis for administering dexamethasone after intravenous antibiotics have been started. The power of this study is limited and a larger randomized controlled trial would be necessary to determine the relative efficacy of dexamethasone before and after antibiotics. In the face of a decreasing incidence of disease due to $H$ influenzae such a trial is probably not feasible. A meta-analysis of the trials to date may be useful in evaluating the relationship between the time of administration of dexamethasone and efficacy in reducing hearing loss and neurological sequelae. 
ACKNOWLEDGEMENTS: The authors thank the clinical staff who cared for these patients, in particular, the psychologists and neurologists. Supported by a grant from the Physicians' Services Incorporated Foundation.

\section{REFERENCES}

1. Wenger JD, Hightower AW, Facklam RR, Gaventa S, Broome CV, Bacterial Meningitis Study Group. Bacterial meningitis in the United States, 1986: report of a multistate surveillance study. J Infect Dis 1990;162:1316-23.

2. Scheld WF III, Ward JI, Band JD, Hightower A, Fraser DW, Broome CV. Bacterial meningitis in the United States, 1978 through 1981. The national bacterial meningitis surveillance study. JAMA 1985;253:1749-54.

3. Durand ML, Calderwood SB, Weber DJ, et al. Acute bacterial meningitis in adults: A review of 493 episodes. N Engl J Med 1993;328:2 1-8.

4. Pomeroy SL, Holmes SJ, Dodge PR, Feigin RD. Seizures and other neurologic sequelae of bacterial meningitis in children. N Engl J Med 1990;323:1651-7.

5. Taylor HG, Mills EL, Ciampi A, et al. The sequelae of Haemophilus influenzae meningitis in school-age children. N Engl J Med 1990;323:1657-63.

6. Dodge PR, Davis H, Feigin RD, et al. Prospective evaluation of hearing impairment as a sequela of acute bacterial meningitis. N Engl J Med 1984;31 1:869-74.

7. Quagliarello V, Scheld WM. Bacterial meningitis: pathogenesis, pathophysiology, and progress. N Engl J Med 1992:327:864-72.

8. Tunkel AR, Scheld WM. Pathogenesis and pathophysiology of bacterial meningitis. Clin Microbiol Rev 1993;6:1 18-36.

9. Syrogiannopoulos GA. Hansen EJ, Erwin EL, et al. Haemophilus influenzae type b oligosaccharide induces meningeal infllammation. J Infect Dis 1988;157:237-44.

10. Tuomanen E, Liu H, Hengstler B, Zak O, Tomasz A. The induction of meningeal inflammation by components of the pneumococcal wall. J Infect Dis 1985: 151:859-67.

11. Mustafa MM, Ramilo O, Mertsola J, et al. Modulation of inflammation and cachectin activity in relation to treatment of experimental Hemophilus influenzae type b meningitis. J Infect Dis 1989;160:818-25.

12. Mustafa MM, Lebel MH, Ramilo O, et al. Correlation of interleukin-1b and cachectin concentrations in cerebrospinal fluid and outcome from bacterial meningitis. J Pediatr 1989:1 15:208-13.

13. Scheld WM, Dacey RC, Winn HR, Welsh JE, Jane JA. Sande MA. Cerebrospinal fluid outflow resistance in rabbits with experimental meningitis: alterations with penicillin and methylprednisolone. J Clin Invest 1980:66:243-53.

14. Tauber MG, Khayam-Bashi H, Sande MA. Effects of ampicillin and corticosteroids on brain water content. cerebrospinal fluid pressure, and cerebrospinal fluid lactate levels in experimental pneumococcal meningitis. $\mathrm{J}$ Infect Dis 1985;151:528-34.

15. Syrogiannopoulos GA, Olsen KD, Reisch JS, McCracken GH Jr. Dexamethasone in the treatment of Haemophilus influenzae type b meningitis. J Infect Dis 1987;155:2 13-9. (Erratum, J Infect Dis 1987:155:1359.)

16. Lebel MH, Freij BJ, Syrogiannopoulos GA, et al. Dexamethasone therapy for bacterial meningitis. Results of two double-blind, placebo-controlled trials. N Engl J Med 1988;319:964-71.

17. Odio CM, Faingezicht I, Paris M, et al. The beneficial effects of early dexamethasone administration in infants and children with bacterial meningitis. N Engl J Med 1991;324:1525-31.

18. Schaad UB, Lips U, Gnehm HE, Blumberg A, Heinzer I, Wedgwood J, and the Swiss Meningitis Study Group. Dexamethasone therapy for bacterial meningitis in children. Lancet 1993:342:457-61.

19. Wald E, and US Meningitis Study Group. Dexamethasone for children with bacterial meningitis. Program and Abstracts of the 32nd Interscience Conference on Antimicrobial Agents and Chemotherapy. Anaheim: American Society for Microbiology, 1992:123. (Abst)

20. Mustafa MM, Ramilo O, Merstola J, et al. Modulation of inflammation and cachectin activity in relationship to experimental Haemophilus influenzae type b meningitis. $\mathrm{J}$ Infect Dis 1989:160:818-25.

21. Velasco S, Tarlow M, Olsen K, Shay JW, McCracken GH $\mathrm{Jr}$, Nisen PD. Temperature-dependent modulation of lipopolysaccharide-induced interleukin- $1 \mathrm{~b}$ and tumor necrosis factor $\alpha$ expression in cultured human astroglial cells by dexamethasone and indomethacin. J Clin Invest 1991;87:1674-80.

22. Mustafa MM, Ramilo O, Saez-Llorens X, Olsen KD, Magnes RR, McCracken GH. Cerebrospinal fluid prostaglandins, interleukin $1 \mathrm{~b}$, and tumor necrosis factor in bacterial meningitis. Clinical and laboratory correlations in placebo-treated and dexamethasonetreated patients. Am J Med Child 1990;144:883-7.

23. American Academy of Pediatrics Committee on Infectious Diseases. Dexamethasone therapy for bacterial meningitis in infants and children. Pediatrics 1990;86:130-3.

24. The Meningitis Working Party of the British Immunology and Infectious Diseases Group. Should we use dexamethasone in meningitis? Arch Dis Child 1992;67:1398-401.

25. Jennett B, Teasdale G. Aspects of coma after severe head injury. Lancet 1977;i:878-81.

26. James HE. Neurological evaluation and support in the child with an acute brain insult. Pediatr Ann 1986; 15:16-22.

27. Herson VC, Todd JK. Prediction of morbidity in Haemophilus influenzae meningitis. Pediatrics 1977;59:35-9.

28. American Speech-Language-Hearing Association (ASHA), Committee on Infant Hearing. Guidelines for the audiologic assessment of children from birth through 36 months of age. ASHA 1991;33(Suppl 5):37-43.

29. Thompson M, Wilson WR. Clinical application of the visual reinforced audiometry. Semin Hearing 1984;5:85-99

30. deLemos RA, Hagerty RJ. Corticosteroids as an adjunct to the treatment in bacterial meningitis. Pediatrics 1969:44:30-4.

31. Belsey MA. Hoffpauir CW, Smith MHD. Dexamethasone in the treatment of acute bacterial meningitis. Pediatrics 1969:44:503-13.

32. Schaad UB, Suter S, Gianella-Borrradori A, et al. A comparison of ceftriaxone and cefuroxime for the treatment of bacterial meningitis in children. N Engl J Med 1990;322:141-7.

33. Navas L, King SM, Gold R. Initial therapy of bacterial meningitis with cefuroxime: Experience in 167 children. Can J Infect Dis 1992;3:162-6.

34. Peltola H, Anttila M, Renkonen O, et al. Randomized comparison of chloramphenicol, ampicillin, cefotaxime and ceftriaxone for childhood bacterial meningitis. Lancet 1989;i: $1281-7$.

35. Vienny H. Despland PA, Lutschg J. Deonna T, DutoitMarco ML, Gander C. Early diagnosis and evolution of deafness in childhood meningitis: a study using brainstem auditory evoked potentials. Pediatrics 1984;73:579-86.

36. Kaplan SL, Catlin FI, Weaver T, Feigin RD. Onset of hearing loss in children with bacterial meningitis. Pediatrics 1984;73:575-8.

37. Schiefele D, Gold R, Law B, et al. Decline in Haemophilus influenzae type b invasive infections at five Canadian pediatric centres. Can Commun Dis Rep 1993;19:88-91. 


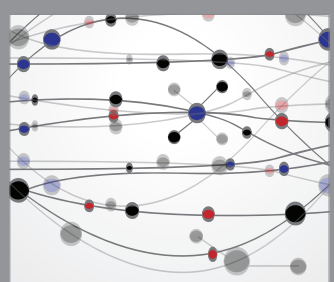

The Scientific World Journal
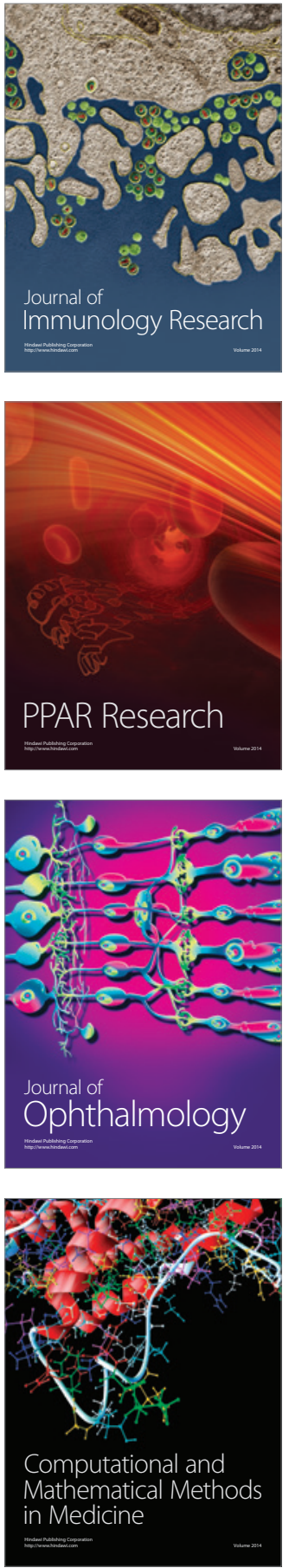

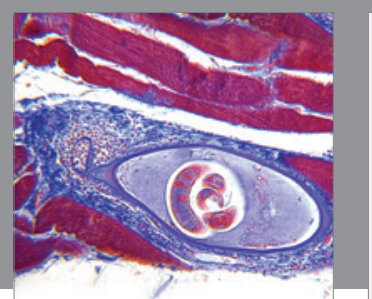

Gastroenterology Research and Practice

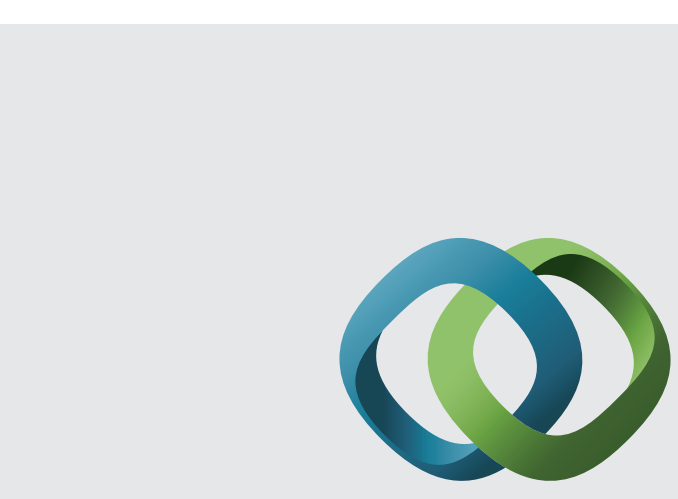

\section{Hindawi}

Submit your manuscripts at

http://www.hindawi.com
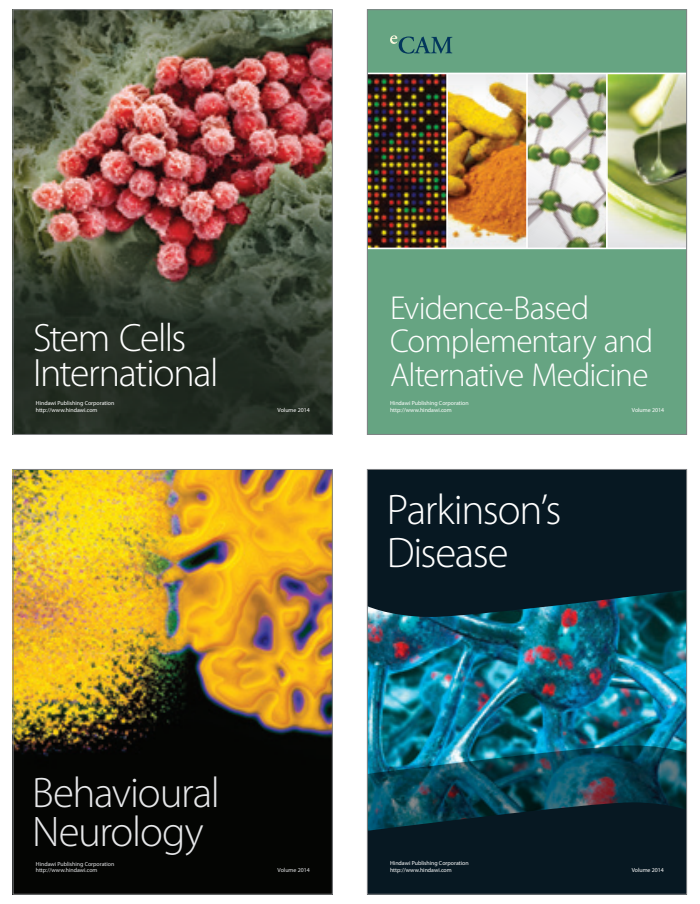
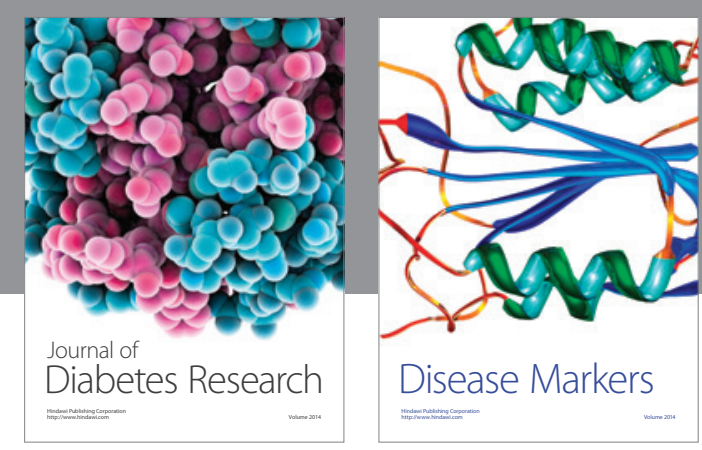

Disease Markers
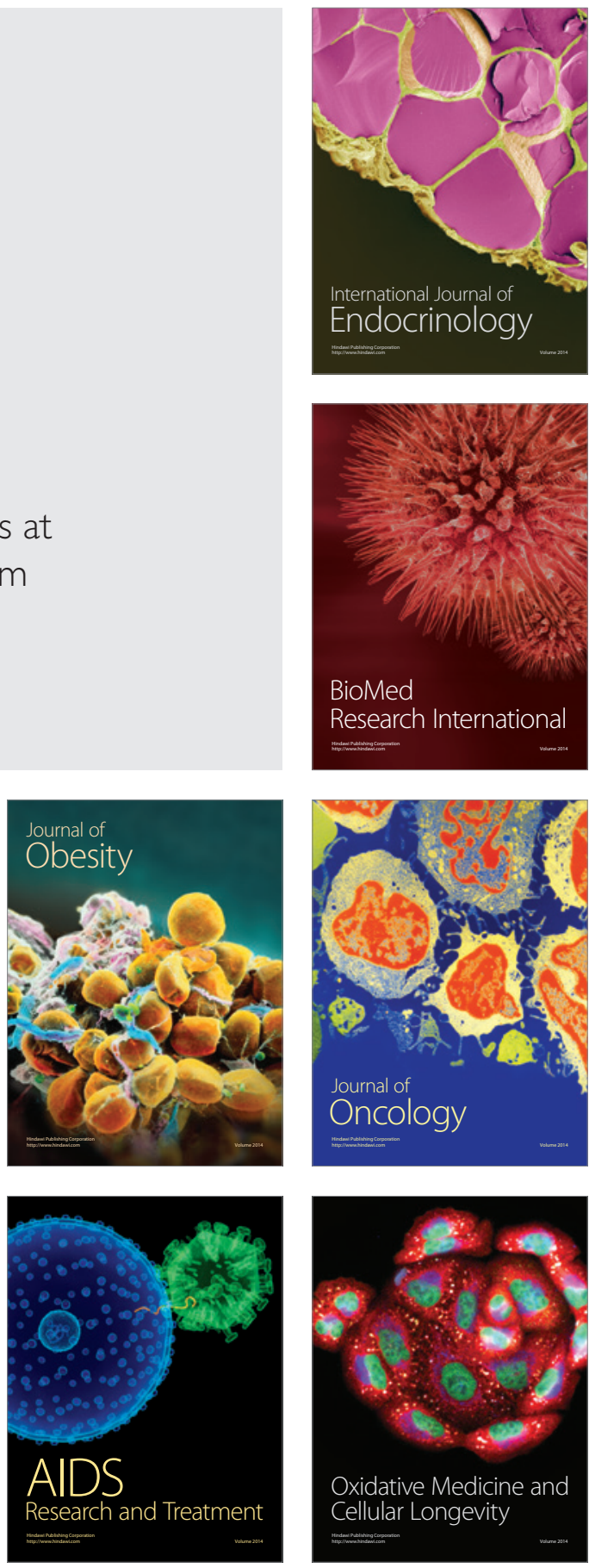